\title{
Application of Problem Based Learning Model with SETS Vision to Increase Students' Learning Motivation on Environmental Pollution Material
}

\author{
Fatimahwati ${ }^{*}$, Yusrizal ${ }^{2}$, Zarlaida Fitri ${ }^{3}$, Hafnati Rahmatan ${ }^{4}$, Ibnu Khaldun ${ }^{3}$ \\ 1 Science Education Study Program Postgraduate Program Syiah Kuala University, Aceh, Indonesia. \\ ${ }^{2}$ Physics Education Study Program, FKIP Syiah Kuala University, Aceh, Indonesia. \\ ${ }^{3}$ Chemistry Education Study Program, FKIP Syiah Kuala University, Aceh, Indonesia. \\ ${ }^{4}$ Biology Education Study Program, FKIP Syiah Kuala University, Aceh, Indonesia.
}

DOI: $\underline{10.29303 / j p p i p a . v 7 i 3.715}$

\section{Article Info}

Received: March 25th, 2021

Revised: May 3th 2021

Accepted: May 25th, 2021

\begin{abstract}
This study aims to determine the increase in learning motivation and student responses to the application of the Problem Based Learning model with SETS vision on environmental pollution material at SMP Negeri 8 Banda Aceh. This research is a quantitative study using an experimental research design in the form of a nonequivalent control group design. The number of students in this study was 40 students consisting of 20 students in class VII-5 as the experimental class and 20 students in class VII-7 as the control class. Data were collected through a motivation questionnaire and a response questionnaire. Data analysis was carried out quantitatively. The results showed that the implementation of the PBL model with SETS vision can increase students' learning motivation on environmental pollution material. The average learning motivation of experimental class students increased by 30 with an N-Gain score of 0.74 which is in the high category. The positive response of students is higher than the negative response to the application of the Problem Based Learning (PBL) model with SETS vision on environmental pollution material. The average response of students is greater than 81 which is in very good criteria.
\end{abstract}

Keywords: Problem Based Learning Model; SETS; motivation; environmental pollution

Citation: $\quad$ Fatimahwati, F., Yusrizal, Y., Fitri, Z., Rahmatan, H., \& Khaldun, I. (2021). Application of Problem Based Learning Model with SETS Vision to Increase Students' Learning Motivation on Environmental Pollution Material. Jurnal Penelitian Pendidikan IPA, 7(3), 310-316. doi:https://doi.org/10.29303/jppipa.v7i3.715

\section{Introduction}

Learning will be of higher quality if the communication process between educators and students runs smoothly. The subject matter, methods, and theories of science learning in schools are expected to be integrated with the daily life of students (Roth, 2012). The learning process should emphasize providing direct experience to develop competencies in order to explore and understand so that students can understand the natural surroundings scientifically. Therefore, teachers need to strive for innovative ways in the learning process so that all the information submitted can be well received and understood by students.

Education in Aceh Province is currently still not satisfactory and not optimal even though the Aceh government has spent a lot of budget funds to finance many projects in an effort to improve the quality of education (Lesmana, 2018). The quality of education in Aceh has not shown optimal results on student learning outcomes, especially in science learning. This can be seen from the low results of the National Examination for Science subjects for junior high school 
level in Aceh province at the national level with an average of 40.84, while the national average is around 47.47 (Puspendik, 2019).

SMP Negeri 8 is one of the junior high schools in the city of Banda Aceh which is ranked 25th out of 42 SMP and MTs or 22nd out of 32 SMP in Banda Aceh City. The average score of the national examination for science subjects in 2019 was 37.74 which was lower than the average score for the national exam in Banda Aceh which was 47.23. When compared with all SMP/MTs in Banda Aceh, SMP Negeri 8 is in the 35th rank of 42 schools based on the National Exam scores for Science Subjects (Puspendik, 2019).

The results of the researcher's observations can be seen that the learning process that takes place does not fully reflect the learning process with the application of the 2013 curriculum which requires students to be active and directly involved in the problem-solving process. This can be seen from several teacher activities that still dominate the process of delivering material in class, namely the teacher teaching using the meaningful lecture method. Students only pay attention to the teacher who explains in front of the class and then works on the assignment given with the references in the student handbook given at school. So it can be seen that when learning students still do not show a confident attitude in asking questions and expressing opinions during learning activities, are not enthusiastic in the learning process, there are still those who talk to friends when the teacher is explaining the lesson.

This shows that students are less motivated in learning, so they are less involved in participating in completing tasks given by the teacher. Based on the questionnaire distributed, it can be seen that the average percentage of students 'motivation is $60 \%$, which indicates that the student's motivation in learning is in the medium category.

The readiness of students to learn is the most important factor in determining the success of students in learning (Mulyani, 2013). Many factors affect the readiness of students to succeed in the learning process, including educators, students, the environment, methods or techniques, and learning media. The learning motivation and thinking ability of students will increase if the science teacher can develop learning tools that are more interesting, varied, and in accordance with the students' circumstances (Susilo, 2012).

One of the science learning materials in SMP is environmental pollution material which is Basic Competency 3.8. Environmental pollution material analyzes the occurrence of environmental pollution and its impact on the ecosystem.
One solution to overcoming the above problems is to apply an attractive learning model in the learning process (Twyman \& Heward, 2018). The learning model is Problem Based Learning with SETS (Science Environment Technology and Society) vision. The PBL model with the SETS vision is more effective in improving science problem-solving abilities than conventional methods (Wasiso, 2013).

Problem-Based Learning is a learning model that focuses on the core concepts and principles of a discipline, facilitating students to be actively involved in investigating, solving real-world problems, other meaningful tasks, and producing real products with the aim of increasing motivation, level thinking skills. height, understand the material thoroughly and improve the process skills of students. The application of the PBL learning model affects cognitive learning outcomes (Ismayawati \& Purwoko, 2016) and science learning motivation (Kusnandar, 2019) and can improve students' metacognition skills (Ramdoniati, et.al., 2019).

Education with the SETS vision can guide students to think and act globally and locally in solving daily problems in an integrated manner in a reciprocal relationship between elements of science, namely the Science Environment Technology and Society (Khasanah, 2015). The SETS approach is centered on problems in the environment or the real world that have a science and technology component in which there are concepts and processes so that they can invite students to investigate, analyze, apply these concepts and processes to real situations (Fatchan, et.al. ., 2014; Usmeldi, et al., 2017).

The PBL learning model with the SETS vision focuses on the selected problem so that students not only learn the concepts related to the problem but also the scientific method to solve the problem. This learning model is in accordance with the application of the 2013 curriculum which emphasizes the scientific approach to the learning process and uses the scientific way to deal with a problem or problem-based learning.

\section{Method}

This research is quantitative. The experimental research design used in this study was in the form of a nonequivalent control group design to determine the differences in the abilities of the treated class and the untreated class.

The population in this study were all class VII students of SMP Negeri 8 Banda Aceh in the 2019/2020 school year, totaling 219 students. The sampling technique in this study was purposive sampling. The sample in this study was class VII-5 as the experimental 
class and class VII-7 as the control class, each class consisting of 20 students.

The research instrument was a student motivation questionnaire and a student response questionnaire. The student motivation questionnaire sheet used in this study was based on the motivation theory of attention, relevance, confidence, and stratification (ARCS) developed by Keller (1987). This motivation questionnaire uses a Likert 1-5 scale which contains five answer choices, namely strongly agree, agree, doubt, disagree, and strongly disagree.

The motivation questionnaire was given twice to the control class and twice to the experimental class. The first motivation questionnaire is given before the implementation of the learning process which aims to determine the initial motivation of students, while the second is given after the learning process is carried out which aims to determine the increase in learning motivation of students after being given treatment. The student response questionnaire aims to find out students' responses regarding the implementation of the PBL learning model with the SETS vision.

The analysis of students' learning motivation questionnaire is calculated by using the percentage formula. After the value is obtained, the results are interpreted using the formula adopted from Sugiyono (2014) which can be seen in Table 1.

Table 1. Range of students' learning motivation scores

\begin{tabular}{lll}
\hline No & Motivation value $(\%)$ & Category \\
\hline 1 & $81-100$ & Very Good \\
2 & $61-80$ & Good \\
3 & $41-60$ & Worth \\
4 & $21-40$ & less \\
5 & $<21$ & Very Less \\
\hline
\end{tabular}

Analysis of the student response questionnaire data was changed in the form of a percentage. Based on the percentage, it will be known that students' responses are included in the positive or negative category. Furthermore, the value is interpreted as in Table 2.

Table 2. Criteria for assessing student responses

\begin{tabular}{lll}
\hline No & Percentage of Student Response & Category \\
\hline 1 & $81-100$ & Very Good \\
2 & $61-80$ & Good \\
3 & $41-60$ & Worth \\
4 & $21-40$ & Less \\
5 & $<21$ & Very Less \\
\hline
\end{tabular}

The increase in students' motivation to learn is seen using the $\mathrm{N}$-gain. The data obtained can be calculated $\mathrm{N}$-gain with the following formula.

$$
N-\text { gain }=\frac{s_{\text {past }}-s_{\text {pre }}}{s_{\text {maks }}-s_{\text {pre }}}
$$

Information:

$$
\begin{array}{ll}
\mathrm{S}_{\text {post }} & =\text { Final test score } \\
\mathrm{S}_{\text {pre }} & =\text { Initial test score } \\
\mathrm{S}_{\max } & =\text { Maximum score }
\end{array}
$$

Table 3: N-gain interpretation

\begin{tabular}{lll}
\hline No & $\mathrm{N}$-gain score & Category \\
\hline 1 & $\mathrm{~N}$-gain $>0.7$ & High \\
2 & $0.3 \leq \mathrm{N}$-gain $\leq 0.7$ & Medium \\
3 & $\mathrm{~N}$-gain $<0.3$ & Low \\
\hline
\end{tabular}

\section{Result and Discussion}

\section{Analysis of Students' Learning Motivation}

Student motivation to learn is an effort within students to master knowledge in order to achieve their goals and as a driving force and effort of students in achieving learning achievement. Huang \& Hew (2016) stated that motivation has a complex and influential effect on the learning process. To find out the learning motivation of students before and after applying the learning treatment to the experimental class and control class, each class will be distributed a motivation questionnaire. In this case, the measured motivation in the form of ARCS motivation consists of four indicator aspects in the form of attention, relevance, confidence, and satisfaction.

The motivation in this study was analyzed in two classes, namely the experimental class by applying the SETS vision learning model, then in the control class through conventional learning using the direct learning model. Students' learning motivation was analyzed to see the average difference test between the experimental class and the control class as well as the $\mathrm{N}$-gain analysis. Before doing this test, first, know the results of the average learning motivation of students in the experimental class and control class in Figure 1.

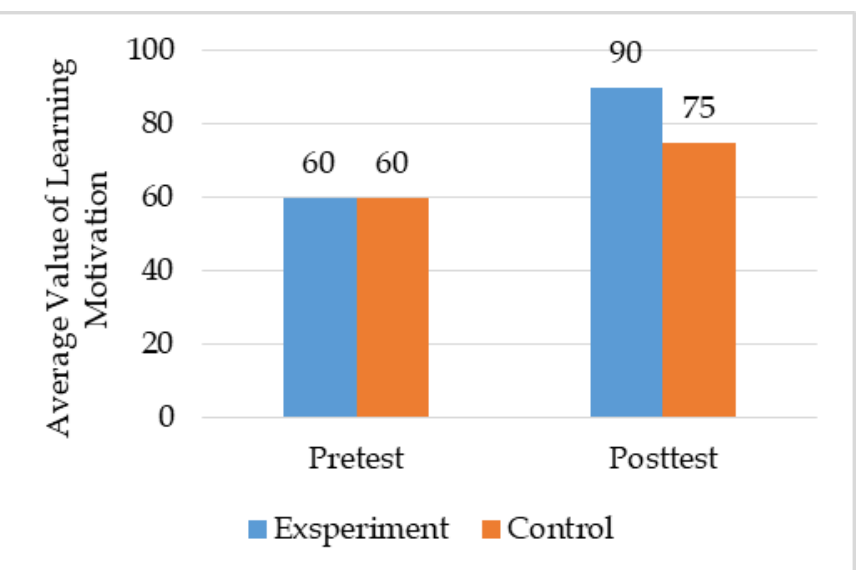

Figure 1. The Average Score of Students' Learning Motivation 
Figure 1 shows the results of the analysis of student learning motivation before and after applying the learning treatment, both in the experimental class and the control class. Students' learning motivation in the experimental class after applying the PBL model with SETS vision obtained an average of 60 pretests and 90 posttests, then in the control class obtained pretest 60 and posttest 74 . Based on the results obtained proves that the application of the PBL model with SETS vision can increase learning motivation students are higher than in the control class who apply the direct learning model.

To find out the increase in the learning motivation of students in the experimental class and control class which is analyzed using the $\mathrm{N}$-gain equation, it can be seen in table 4 .

Table 4. N-gain Analysis of Students' Learning Motivation

\begin{tabular}{llll}
\hline No & Classes & N-gain Values & Category \\
\hline 1 & Experiment & 0.74 & High \\
2 & Control & 0.39 & Medium \\
\hline
\end{tabular}

Table 4 shows that the results of the $\mathrm{N}$-gain analysis of students' learning motivation in the experimental class obtained a score of 0.74 including the high category, then the results of the $\mathrm{N}$-gain analysis in the control class obtained a score of 0.39 including the moderate category. Based on the results of the N-gain analysis in the two classes, it can be concluded that the implementation of the PBL model with the SETS vision can increase the learning motivation of students higher than the application of the conventional model in the form of direct learning.

To find out the different tests of the average learning motivation of students in the experimental class and control class, it can be seen from the average results of students through $\mathrm{N}$-gain analysis using the Mann Whitney test, so it can be seen in table 5 .

Table 5. Difference Test Results Two Average Increased Learning Motivation of Students

\begin{tabular}{lllll}
\hline Data & $\mathrm{N}$ & $\begin{array}{l}\mathrm{U} \text { (signify- } \\
\text { cance value })\end{array}$ & $\begin{array}{l}\mathrm{Ua} \\
(\mathrm{U} \text { table })\end{array}$ & $\begin{array}{l}\text { Declara- } \\
\text { tion }\end{array}$ \\
\hline $\begin{array}{l}\text { Experiment } \\
\text { Control }\end{array}$ & 20 & 0.000 & 0.05 & $\begin{array}{l}\text { Ho is } \\
\text { rejected }\end{array}$ \\
\hline
\end{tabular}

Table 5 shows that the results of the twodifference test analysis of the average learning motivation of students obtained a significance value of $0.000<0.05$, so it can be stated that $\mathrm{H} 0$ is rejected and $\mathrm{Ha}$ is accepted. This means that there is a significant difference in the learning motivation of students in the experimental class and the control class. It can be concluded that the implementation of the PBL model with the SETS vision can increase students' learning motivation better than the control class that applies conventional learning in the form of direct learning. This is in accordance with research conducted by Son (2017) that the application of problem-based learning has an effect on students' motivation to learn in a better direction because problem-based learning provides a clear comprehension of the learning process. The results obtained indicate that the motivation of these students is in a high categorization so that it can be concluded that learning with the SETS vision of the PBL model has an effect on student motivation.

The results of the analysis of students' learning motivation, each indicator measured using a questionnaire instrument consisted of attention, relevance, confidence, and satisfaction. Keller (2016) says that attention includes research on curiosity and passion, interests, boredom, and other related areas such as the search for sensations. Relevance refers to students' perceptions that instructional requirements are consistent with their goals, match or match their learning styles, and are connected to past experiences. Confidence refers to the effect of positive expectations for success, successful experiences, and attributions of success to one's own abilities and efforts rather than luck or to challenge too easy or difficult levels. The fourth condition of motivation is satisfaction, this is intrinsic and extrinsic motivation to study behavior and prevent undesirable ones.

The results of the analysis of students' learning motivation for each indicator before and after giving learning treatment can be seen in Table 6 .

Table 6. Analysis of Students' Learning Motivation Indicators before Treatment

\begin{tabular}{llllll}
\hline \multirow{2}{*}{ No } & \multirow{2}{*}{ Indikator } & \multicolumn{2}{c}{ Experiment Class } & \multicolumn{2}{c}{ Kelas Control } \\
& & Category & $\%$ & Category \\
\hline 1 & Attention & 60.7 & Worth & 60.8 & Worth \\
2 & Relevance & 60.3 & Worth & 60.4 & Worth \\
3 & Convidence & 59.0 & Worth & 57.3 & Worth \\
4 & Satisfaction & 60.6 & Worth & 60.3 & Worth \\
\hline
\end{tabular}

Table 6 is the result of the analysis of students' learning motivation indicators before applying the learning treatment. The results obtained indicate that before the learning treatment, both in the experimental class and in the control class the students' learning motivation was categorized as quite good. However, after applying the learning treatment to the two classes, student learning motivation also increased better than before. To find out the results of the analysis of students' learning motivation after applying the learning treatment in the experimental class and control class can be seen in Table 7 . 
Table 7. Analysis of Students' Learning Motivation Indicators after Treatment

\begin{tabular}{llllll}
\hline \multirow{2}{*}{ No } & \multirow{2}{*}{ Indicator } & \multicolumn{2}{c}{ Experiment Class } & \multicolumn{2}{c}{ Control Class } \\
& & $\%$ & Category & $\%$ & Category \\
\hline 1 & Attention & 89.2 & Very Good & 73.5 & Good \\
2 & Relevance & 89.9 & Very Good & 76.1 & Good \\
3 & Convidence & 88.1 & Very Good & 75.1 & Good \\
4 & Satisfaction & 92.4 & Very Good & 81.3 & Very Good \\
\hline
\end{tabular}

Table 7 shows the results of the analysis of the learning motivation of indicator students after treatment, in the experimental class applying the SETS vision PBL model and the control class applying conventional learning in the form of a direct learning model. Increasing students 'motivation to learn by applying the PBL model with SETS vision can be seen from the proportion of categories obtained from the answers to students' motivation questionnaires before and after being given treatment.

Based on the results obtained in the experimental class with an average value of $>85$, it is in the very high category, thus proving that the PBL model with SETS vision can improve student learning motivation better. This is in accordance with research conducted by Chiang \& Lee (2016); Silva et.al., (2018); Pratiwi \& Wuryandani (2020) stated that the PBL model with the SETS vision can increase students' learning motivation because this model is able to develop investigative skills, influence creativity and the emergence of good attitudes in participating in learning, be diligent in doing and completing assignments given by the teacher and happy to find solutions to solve problems and actively ask and answer questions during the discussion.

The results of this study are also in accordance with the research conducted by Agusmin et al., (2018) that the learning motivation of students has increased because the desire of students to succeed has emerged from within students, such as trying to study diligently and asking the teacher about the material not yet understood. Students also feel the need to get good learning scores by repeating the material taught at home and completing the assignment given by the teacher as well as possible. Praise given by the teacher makes students more enthusiastic in learning because they feel appreciated.

\section{Student Response Analysis}

Student responses are known by distributing questionnaires to the experimental class after implementing learning through the PBL model with SETS vision on environmental pollution material. After implementing learning through the PBL model with the SETS vision, students' responses will be seen to the learning activities that are taking place. The results of the student response analysis can be seen in figure 2 .

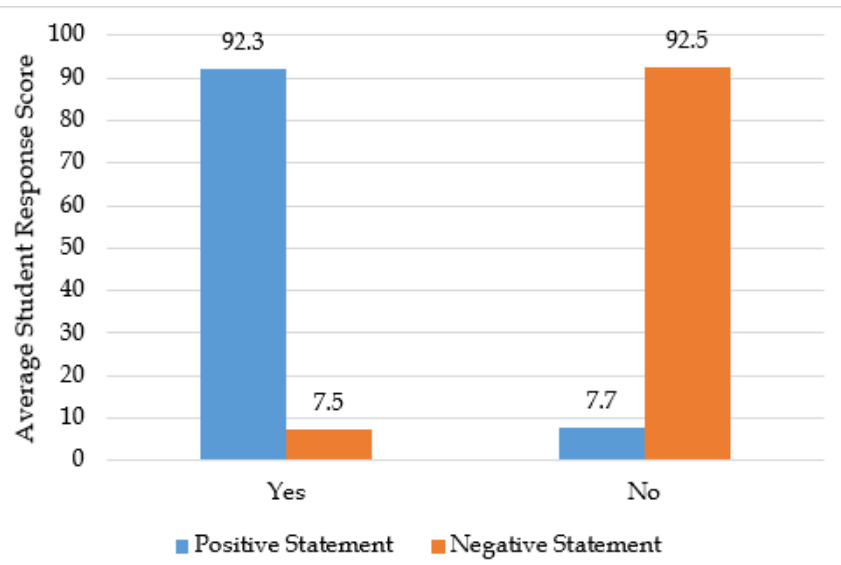

Figure 2. Students' Average Response Score

Figure 2 shows the results of the student response analysis after implementing learning through the SETS vision PBL model. Based on the results of the student response analysis, both positive and negative statements obtained an average score of $>81$ in the very good category. This proves that the implementation of the PBL model with the SETS vision can be accepted by students so that students are motivated and can improve better learning outcomes. This is in accordance with research conducted by Sulardi et.al., (2017); Wismaningati et.al., (2019) said that the responses given by students to the PBL model were very good and positive because the PBL model can train students to identify and solve problems, be diligent in participating in learning and be able to present discussion results based on problem identification. properly and correctly.

\section{Conclusion}

The application of the Problem Based Learning model with the SETS vision can increase students' learning motivation on environmental pollution material with an average N-gain of 0.74 , including the high category. The results of the analysis of students' learning motivation indicators on the indicators Attention $89.2 \%$, Relevance $89.9 \%$, Confidence $88.1 \%$, and Satisfaction $92.4 \%$, so that the four indicators fall into the very good category. The response of students to the implementation of the SETS vision model on environmental pollution material obtained an average score of $>81$ in the very good category. The average percentage results on positive statements that answered "Yes" with a score of $92.3 \%$ and negative statements that answered "No" with a score of $92.5 \%$. 


\section{References}

Agusmin, R., Nirwana, N., \& Rohadi, N. (2018). Peningkatan Motivasi dan Hasil Belajar Siswa dengan Model Problem Based Learning Berbantuan Simulasi PhET di Kelas XI IPA-C SMAN 6 Kota Bengkulu. Jurnal Kumparan Fisika, 1(2),

53-59. doi: $\quad$ https://doi.org/10.33369/jkf.1.2.53-59. [Indonesian]

Chiang, C. L., \& Lee, H. (2016). The effect of projectbased learning on learning motivation and problem-solving ability of vocational high school students. International Journal of Information and Education Technology, 6(9), 709-712. Retrieved from http://www.ijiet.org/vol6/779EP00028.pdf

Fatchan, A., Soekamto, H., \& Yuniarti, Y. (2015). Pengaruh Model Pembelajaran Science, Environment, Technology, Society (SETS) Terhadap Kemampuan Berkomunikasi Secara Tertulis Berupa Penulisan Karya Ilmiah Bidang Geografi Siswa SMA. Jurnal Pendidikan dan Pembelajaran (JPP), 21(1), 33-40. Retrieved from http://journal.um.ac.id/index.php/pendidikandan-pembelajaran/article/view/4520.

[Indonesian]

Huang, B., \& Hew, K. F. T. (2016). Measuring learners' motivation level in massive open online courses. International Journal of Information and Education Technology, 6 (10), 759-764. Retrieved from http://www.ijiet.org/vol6/788-A001.pdf

Ismayawati, B., Purwoko, A., \& Muntari, M. (2016). Pengaruh Model Pembelajaran Berbasis Masalah (PBM) dalam Setting Pembelajaran Kooperatif Tipe TGT dan GI terhadap Keterampilan Berpikir Kritis dan Hasil Belajar Kimia Peserta Didik SMAN 1 Aikmel. Jurnal Penelitian Pendidikan IPA, 2(1). doi:https://doi.org/10.29303/jppipa.v2i1.33. [Indonesian]

Keller, J. M. (1987). Development and use of the ARCS model of instructional design. Journal of instructional development, 10(3), 2-10. Retrieved from

https://link.springer.com/article/10.1007\%2FBF $\underline{02905780}$

Keller, J. M. (2016). Motivation, learning, and technology: Applying the ARCS-V motivation model. Participatory Educational Research, 3(2), 115. https://doi.org/10.17275/per.16.06.3.2

Khasanah, N. (2015). SETS (Science, Environment, Technology and Society) sebagai Pendekatan Pembelajaran IPA Modern pada Kurikulum 2013. Prosiding KPSDA, 1 (1), 270-277. Retrieved from

https://core.ac.uk/download/pdf/289792431.p df.

Kusnandar, D. (2019). Pengaruh model problem based learning terhadap hasil belajar kognitif dan motivasi belajar IPA. Madrascience: Jurnal Pendidikan Islam, Sains, Sosial, dan Budaya, 1(1), 15-26. Retrieved from http://madrascience.com/index.php/ms/article $\angle$ view/62. [Indonesian]

Lesmana, S. (2018). Analisis Mutu Pendidikan Aceh. Retrieved from: https://docplayer.info/56850449-Analisis-mutupendidikanaceh.html\#show_full_text. Diakses pada tanggal 12 Juli 2019. [Indonesian]

Mulyani, D. (2013). Hubungan Kesiapan Belajar Siswa dengan Prestasi Belajar. Jurnal Ilmiah Konseling, 2 (1): 27-31. doi: https://doi.org/10.24036/0201321729-0-00. [Indonesian]

Pratiwi, V. D., \& Wuryandani, W. (2020). Effect of Problem Based Learning (PBL) Models on Motivation and Learning Outcomes in Learning Civic Education. JPI (Jurnal Pendidikan Indonesia), 9(3), 401-412. doi: $\quad$ http://dx.doi.org/10.23887/jpiundiksha.v9i3.21565

Pusat Penilaian Pendidikan Kementerian Pendidikan dan Kebudayaan (Puspendik). (2019). Hasil Ujian NAsional. Retrieved from https://puspendik.kemdikbud.go.id/hasil-un/. Diakses pada tanggal 12 Juli 2019. [Indonesian]

Ramdoniati, N., Muntari, M., \& Hadisaputra, S. (2018). Pengembangan Bahan Ajar Kimia Berbasis Problem Based Learning untuk Meningkatkan Keterampilan Metakognisi. Jurnal Penelitian Pendidikan IPA, 5(1). doi:https://doi.org/10.29303/jppipa.v5i1.148. [Indonesian]

Roth, W. M. (2012). Science of learning is learning of science: why we need a dialectical approach to science education research. Cultural studies of science education, 7(2), 255-277. Retrieved from https://link.springer.com/article/10.1007/s1142 2-012-9390-6.

Silva, A. B. D., Bispo, A. C. K. D. A., Rodriguez, D. G., \& Vasquez, F. I. F. (2018). Problem-based learning: A proposal for structuring PBL and its implications for learning among students in an undergraduate management degree program. Revista de Gestão, 25(2), 160-177. https://doi.org/10.1108/REGE-03-2018-030

Son, R. S. S. (2017). Pembelajaran Bervisi Sets Model Problem Based Learning Pada Materi Daur Ulang Limbah. Scholaria: Jurnal Pendidikan Dan 
Kebudayaan, 7(3), 257-266. doi: https://doi.org/10.24246/j.scholaria.2017.v7.i3.p 257-266. [Indonesian]

Sugiyono. (2014). Metode Penelitian Pendidikan Pendekatan Kuantitatif, Kualitatif, dan $R \in \mathcal{E} D$. Bandung: Alfabeta. [Indonesian]

Sulardi, S., Nur, M., \& Widodo, W. (2017). Pengembangan Perangkat Pembelajaran Fisika Model Problem Based Learning (PBL) Untuk Melatih Keterampilan Berpikir Kritis Siswa. JPPS (Jurnal Penelitian Pendidikan Sains), 5(1), 802-810. doi: http://dx.doi.org/10.26740/jpps.v5n1.p802810. [Indonesian]

Susilo, A. (2012). Pengembangan Model Pembelajaran Ipa Berbasis Masalah Untuk Meningkatkan Motivasi Belajar Dan Berpikir Kritis Siswa SMP. Journal of Primary Education, 1(1). https://doi.org/10.15294/jpe.v1i1.58.

[Indonesian]

Twyman, J. S., \& Heward, W. L. (2018). How to improve student learning in every classroom now. International Journal of Educational Research, 87 , 78-90. https://doi.org/10.1016/j.ijer.2016.05.007.

Usmeldi, U., Amini, R., \& Trisna, S. (2017). The development of research-based learning model with science, environment, technology, and society approaches to improve critical thinking of students. Jurnal Pendidikan IPA Indonesia, 6(2), 318-325. doi: https://doi.org/10.15294/jpii.v6i2.10680

Wasiso, S. J. (2013). Implementasi Model Problem Based Learning Bervisi SETS untuk Meningkatkan Kemampuan Pemecahan Masalah IPA dan Kebencanaan oleh Siswa. Journal of Innovative Science Education, 2(1), 63-67. Retrieved from https://journal.unnes.ac.id/sju/index.php/jise/ article/view/3128. [Indonesian]

Wismaningati, P., Nuswowati, M., Sulistyaningsih, T., \& Eisdiantoro, S. 2019. Analisis Keterampilan Proses Sains Materi Koloid Melalui Pembelajaran Berbasis Proyek Bervisi SETS. Jurnal Inovasi Pendidikan Kimia, 13(1), 2287-2294. Retrieved from

https://journal.unnes.ac.id/nju/index.php/JIPK Larticle/view/15154. [Indonesian] 